\title{
Evaluation of active paper in conservation and postharvest quality of strawberry
}

Débora Monique Vitor ${ }^{1} \oplus$, Hiasmyne Silva de Medeiros ${ }^{1} \oplus$, Nilda de Fátima Ferreira Soares ${ }^{1}\left[\right.$, Eber Antônio Alves Medeiros ${ }^{1}(\mathbb{0}$

${ }^{1}$ Universidade Federal de Viçosa, Viçosa-MG, Brasil. E-mail: deboramv@yahoo.com.br; hiasmyne@yahoo.com.br; nfsoares@ufv.br; ebermedeiros@yahoo.com.br

ABSTRACT: During the postharvest stage of the strawberry, considerable losses can be caused mainly by the attack of phytopathogenic fungi. An alternative to the use of fungicides is the essential oil (EO) incorporated in the packaging in order to control these microorganisms. This study developed active paper with $2.5,5,7$ and $10 \%$ of the cinnamaldehyde EO and evaluated its antifungal properties against Rhizopus stolonifer and Botrytis cinerea. Subsequently, strawberries were placed in "nests" made with the active paper produced with $5 \% \mathrm{OE}$, stored at refrigeration temperature $\left(8^{\circ} \mathrm{C}\right)$ and evaluated for its microbiological and physicochemical parameters at the times of $0,3,6,9$ and 12 days. The physicochemical analyzes of the fruit showed difference $(p>0.05)$ between the treatments for the firmness and fruit color. The reduction in the growth of filamentous fungi, yeasts and aerobic mesophiles was verified in the microbiological results of strawberries wrapped in the active paper. It is concluded that the use of the active paper incorporated with EO in strawberries composes an alternative in the substitution of agrochemicals, with potential application in other fruits.

Key words: antifungal activity; essential oil; Fragaria x ananassa Duch.

\section{Avaliação de papel ativo na conservação e na qualidade pós-colheita de morango}

RESUMO: Durante a etapa de pós-colheita do morango podem ocorrer consideráveis perdas causadas principalmente pelo ataque de fungos fitopatogênicos. Uma alternativa ao uso de fungicidas é o óleo essencial (OE) incorporado na embalagem para o controle desses micro-organismos. Este trabalho desenvolveu papel ativo incorporado com 2,5, 5, 7 e $10 \%$ do $\mathrm{OE}$ de cinamaldeído e avaliou as suas propriedades antifúngicas contra Rhizopus stolonifer e Botrytis cinerea. Posteriormente, morangos foram colocados em "ninhos" feitos com o papel ativo produzido com $5 \%$ do OE, armazenados à temperatura de refrigeração $\left(8^{\circ} \mathrm{C}\right)$ e avaliados quanto aos parâmetros microbiológicos e físico-químicos nos tempos $0,3,6,9$ e 12 dias. As análises físico-químicas dos frutos apresentaram diferença $(p>0,05)$ entre os tratamentos para firmeza e cor dos frutos. Verificou-se nos resultados microbiológicos redução no crescimento de fungos filamentosos, leveduras e mesófilos aeróbios em morangos acondicionados no papel ativo. Conclui-se que o uso do papel ativo incorporado com OE em morangos constitui uma alternativa na substituição de agroquímicos, com potencial aplicação em outros frutos.

Palavras-chave: atividade antifúngica; óleo essencial; Fragaria $x$ ananassa Duch. 


\section{Introduction}

Strawberry (Fragaria $x$ ananassa Duch.) has a short postharvest life due to the incidence of diseases, specially gray mold and soft rot, caused by Botrytis cinérea and Rhizopus stolonifer, respectively (Costa \& Ventura, 2006). Due to these diseases, several techniques have been developed in the fruit production to control the development of microorganisms, aiming to obtain good quality fruit.

Consumer demands and increasing government restrictions on pesticide use have prompted investigations into the use of new complementary refrigeration technologies. Wei et al. (2018) state that identifying alternative antifungal agents in order to extend postharvest quality if of utmost interest. An alternative in ensuring postharvest safe fruits is the use of natural products such as the essential oil (EO), as it has low risk to the environment, producers and consumers, as well as not favoring the resistance of the pathogen (Derbalah et al., 2012).

Moreover, EOs and their constituents are registered as flavorings by the United States Food and Drug Administration (FDA) and classified as safe (GRAS) (FDA, 2018). The use of essential oils is rising because it has in its composition terpenic substances with antimicrobial action (Moura et al., 2016). Several authors cite the antimicrobial efficiency of EOs in controlling postharvest diseases in strawberry (AguilarGonzález et al., 2015; Boubaker et al., 2016; Campos-Requena et al., 2017; Wei et al., 2018).

Employment of EO-incorporated active packaging has been showing promising results in the phytopathogens control at postharvest. Antimicrobial packaging is a particular class of active packaging that is effective in controlling microbial growth on the packaged foods surface and, hence, extends its shelf life (Kerry, 2014; Cozmuta et al., 2015; Gorrasi et al., 2016). This is resulting from the interaction of packaging with food and/or surrounding environment with the aim of delaying, reducing or even inhibiting the growth of pathogenic and spoilage microorganisms (Espitia et al., 2012).

Thereby, the objective of the present study was to develop an active paper incorporated with cinnamaldehyde EO and to evaluate its effect on controlling Botrytis cinérea and Rhizophus stolonifer in vitro and in the postharvest strawberry, as well as to evaluate the effect of this package on the physicochemical characteristics of strawberry stored under refrigeration.

\section{Materials and Methods}

\section{Plant material}

The strawberries were acquired from the Viçosa-MG retail market and transported to the Packaging Laboratory of the Food Technology Department (UFV), where the healthy and uninjured fruits were then selected and standardized for their physiological maturation.

\section{Active paper}

The active paper was produced with the lecithin emulsion incorporated with $2.5,5,7.5$ and $10 \%$ of cinnamaldehyde, homogeneously mixed and incorporated into the cassava starch gel and applied to the surface of waxed and sulfite paper by the casting process (Soares, 1998). Films were dried at $25{ }^{\circ} \mathrm{C}$. The control treatment consisted of uncoated and coated paper with the filmogenic solution and no essential oil. The used cinnamaldehyde EO was kindly donated by the Petite Marie industry (SP, Brazil).

\section{In vitro antimicrobial efficiency of coated paper}

Evaluation of antimicrobial efficiency of the active films was held by diffusion test in solid culture medium. Phytopathogenic fungi Botrytis cinérea and Rhizopus stolonifer, retrieved from the collection of the Postharvest Laboratory and the Seed Pathology Laboratory of the Federal University of Viçosa, were picked on acidified potato dextrose agar (BDA), in which coated paper discs were placed (10 $\mathrm{mm}$ diameter) with the different EO concentrations. Paper without incorporation of cinnamaldehyde composed the control treatment. The plates were incubated at $25{ }^{\circ} \mathrm{C}$ for 7 days. Antifungal activity of the different elaborated packages was determined from the microbial growth inhibition zone.

Evaluation of the active paper in postharvest packaging of strawberry

Approximately $250 \mathrm{~g}$ of strawberries were put in "nests" made from the produced active paper and placed in expanded polystyrene trays, so that all of them remained in contact with the active packaging, then packaged in properly sealed polyethylene-nylon bags (PE-Nailon). Subsequently, the packaged fruits were stored under refrigeration at $8 \pm 1 \stackrel{\circ}{ } \mathrm{C}$. The same was applied to the control treatments, in which waxed papers without incorporation were used. Strawberries were analyzed at every three days by microbiological and physicochemical analysis for a period of 12 days.

\section{Microbiological evaluation of strawberry}

Evaluation of microbiota development in strawberry wrapped with the active paper was based on the standard counting of aerobic mesophiles on standard counting agar (PCA), and filamentous fungi and yeast on potato dextrose agar (BDA) according to the method described by Vanderzant \& Splittstoesser (2001). Counting was performed at the times of $0,3,6,9$ and 12 days of fruit storage under $8 \pm 1{ }^{\circ} \mathrm{C}$. At 0 time, the strawberry was analyzed shortly after the treatment. Results were obtained with three replicates in triplicate.

\section{Evaluation of physicochemical parameters}

Fresh weight loss was determined by weighing the fruit on a $0.1 \mathrm{~g}$ precision electronic scale and the results were expressed as percentage, considering the difference between the initial fruit weight and the one obtained in each sampling period.

Color change of the fruit epidermis was objectively quantified by means of a colorimeter (COLORQUEST XE) with direct reflectance reading of the coordinate a (relative from green to red). For each sample, the mean of three determinations in random zones of each fruit was used. 
Firmness of the strawberries pulp was evaluated in the INSTRON Material Testing Machine (Series 3367) using a probe ( $3 \mathrm{~mm}$ diameter) with velocity of $5 \mathrm{~mm} / \mathrm{s}$ and penetration distance of $19 \mathrm{~cm}$.

Soluble solids content, titratable acidity and $\mathrm{pH}$ were determined in triplicate in crushed strawberry pulp (10 g) homogenized with $100 \mathrm{~mL}$ of distilled water, according to the AOAC (1995). The pH was measured using the Digimed DM 20 $\mathrm{pH}$ meter.

The postharvest experiment was performed with three replicates in a completely randomized design, $2 \times 5$ factorial scheme (two treatments $x$ five evaluation times: 0, 3, 6, 9 and 12 days), totaling 30 experimental units. Data were subjected to analysis of variance, regression analysis and means test (Tukey at $5 \%$ probability level), all using the statistical program Sisvar (Ferreira, 2011).

\section{Results and Discussion}

\section{In vitro activity of active roles}

Coated papers (waxed and sulfite) with different cinnamaldehyde percentages showed antifungal activity on $R$. stolonifer and $B$. cinérea from the $5 \% \mathrm{EO}$ concentration on (Figure $1 A$ and $1 B)$, observing a difference $(p<0.05)$ between tested EO concentrations.

Antimicrobial efficiency of OEs on $B$. cinérea development in vitro has been confirmed in several previous investigations (Stavropoulou et al., 2014; Aguilar-González et al., 2015). Other authors also proved the efficiency of EO employment in controlling phytopathogenic fungi, such as Lorenzetti et al. (2011), when evaluating the effect of several EOs on the development of $B$. cinérea isolated from strawberry in vitro, verified greater efficiency of cinnamon oil followed by lemon grass and palmarosa by contact.

Waxed paper coated with $5 \%$ cinnamaldehyde showed the greatest inhibition zone of phytopathogenic fungi growth (Figure 1B). Therefore, this packaging allowed greater retention of the EO active constituents and more efficient release of volatile compounds to reach a larger area, indicating greater potential in the fruit postharvest application.

Quattara et al. (2000) also reported the efficiency of antimicrobial films usage resulting from the gradual diffusion of the active ingredient from the packaging to the food surface, maintaining higher concentration in this contact area, as well as several researches report the in vitro antifungal activity of antimicrobial packaging.

\section{Microbiological evaluation of strawberry}

Strawberry fruit with active paper showed a tendency in reducing the development of the evaluated microorganisms in relation to the control treatment during the whole storage period. The active paper showed antimicrobial activity on the counting of aerobic mesophiles, and filamentous fungi and yeast (Figures $2 \mathrm{~A}$ and $2 \mathrm{~B}$ ). These results for the strawberry microbiological quality are in agreement with previous studies
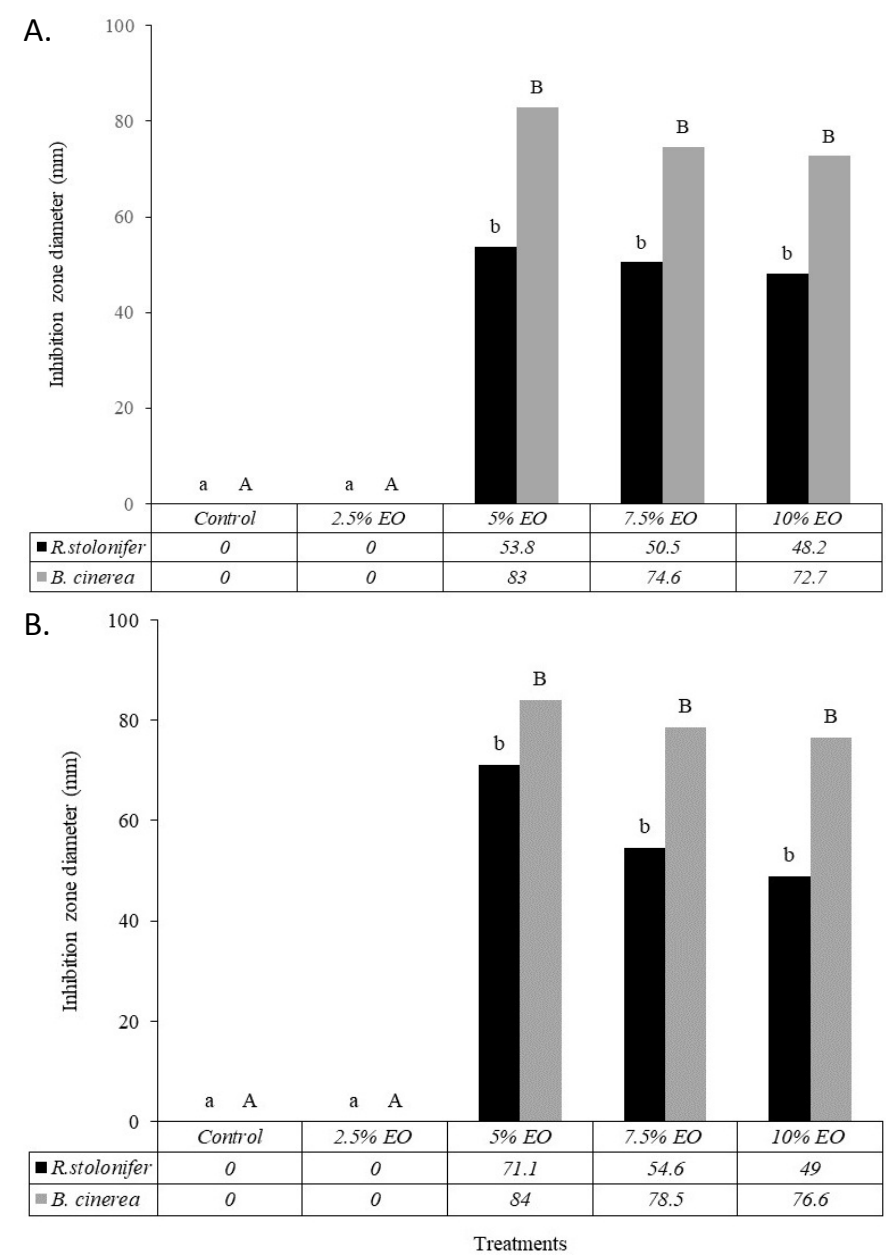

*Means with different letters in the same column, for each type of microorganism, show significant difference $(p<0.05)$ by the Tukey test.

Figure 1. Mean values of the antifungal activity inhibition zones of active packages with sulfite paper (A) and waxed paper (B) on R. stolonifer ( )and B. cinerea ( ) causing postharvest rot in strawberry.

that used the application of essential oils in fruits, directly or by coating them (Garcia et al., 2017; Ventura-Aguilar et al., 2018; Vilaplana et al., 2018).

Espitia et al. (2012) observed similar results in packaged papaya tree fruit in the presence of cinnamon EO antimicrobial sachet, which showed lower values compared to control with a reduction of $1.9 \mathrm{log}$ cycles on the sixth day and $2.2 \mathrm{log}$ cycles on the ninth day, while on the twelfth day it showed a reduction of 1.6 log cycles. Benato et al. (2018) found that the use of cinnamon oil on orange fruits inoculated with $P$. digitatum was more effective as a curative effect.

Physicochemical evaluation of strawberry fruits wrapped in active paper

Physicochemical parameters of strawberry quality, such as firmness, pulp and epidermis color, showed an effect ( $p$ $\leq 0.05$ ) of active paper treatments compared to the control treatments (Table 1). The variables acidity, $\mathrm{pH}$ and soluble solids content of fruit did not differ ( $p>0.05$ ) during storage, nor between treatments and their combinations with storage days (Table 1). 

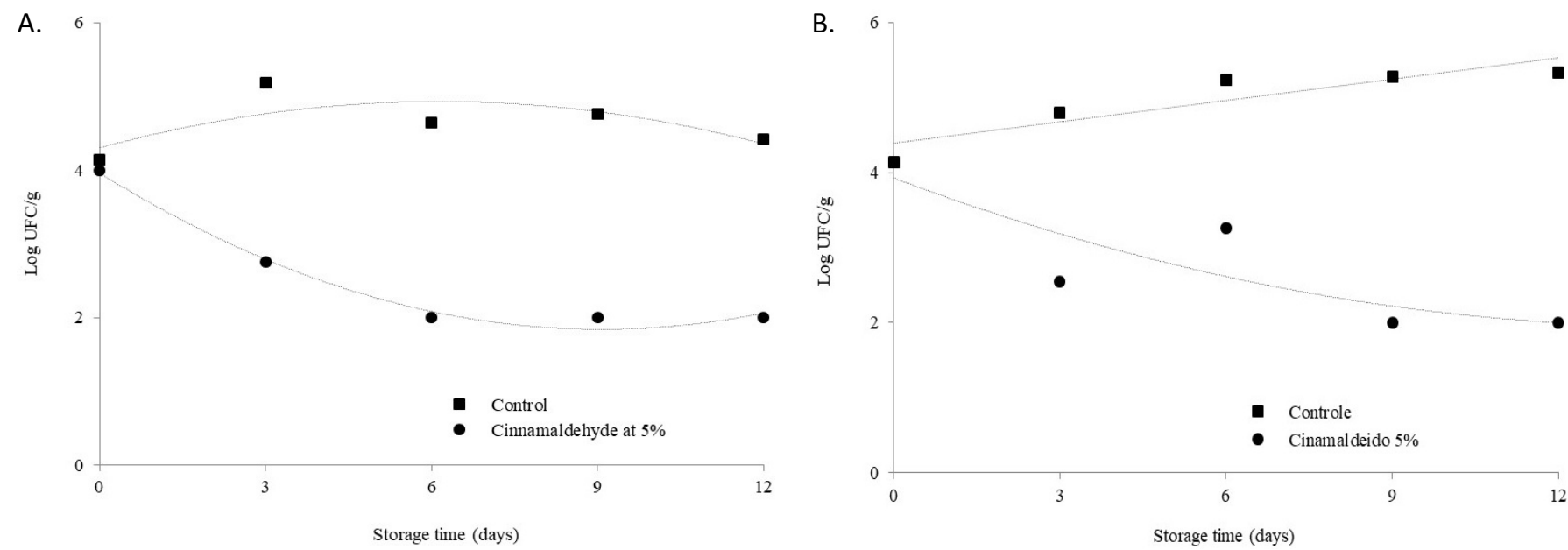

Figure 2. Growth of aerobic mesophiles (Log UFC. $\left.\mathrm{g}^{-1}\right)(A)$, and filamentous fungi and yeast (Log UFC. $\left.\mathrm{g}^{-1}\right)(B)$ in strawberries wrapped in active paper and control under refrigerated $\left(8^{\circ} \mathrm{C}\right)$.

Table 1. Summary of analysis of variance of fresh weight loss, acidity, total soluble solids (TSS), a* color parameter of the pulp and epidermis, as a function of treatments and storage days and their respective coefficients of variation (CV).

\begin{tabular}{lcccccccc}
\hline \multirow{2}{*}{ V.S. } & \multirow{2}{*}{ D.F. } & \multicolumn{7}{c}{ Mean squares } \\
\cline { 3 - 8 } & & FWL (\%) & ACIDITY & pH & SST ( ${ }^{\circ} B$ Brix) & Firmness (N) & $a^{*}$ pulp & $a^{*}$ epidermis \\
\hline Trat. & 1 & $0.00003^{\text {ns }}$ & $0.0158^{\text {ns }}$ & $0.0288^{\text {ns }}$ & $1.0716^{\text {ns }}$ & $4.8642^{*}$ & $17.9491^{*}$ & $106.1448^{* *}$ \\
Day & 4 & $0.07597^{*}$ & $0.4398^{\text {ns }}$ & $0.3832^{\text {ns }}$ & $1.5918^{\text {ns }}$ & $1.3869^{\text {ns }}$ & $26.1628^{\text {ns }}$ & $114.2387^{\text {ns }}$ \\
Trat. x Day & 4 & $0.00136^{\text {ns }}$ & $0.0230^{\text {ns }}$ & $0.01669^{\text {ns }}$ & $1.3313^{\text {ns }}$ & $1.7343^{\text {ns }}$ & $3.5305^{\text {ns }}$ & $42.0575^{\text {ns }}$ \\
Residual & 20 & 0.0077 & 0.0272 & 0.02253 & 0.3356 & 0.66 & 3.9422 & 1.6205 \\
CV (\%) & & 60.05 & 9.89 & 4.06 & 8.08 & 19.77 & 24.32 & 4.9 \\
\hline
\end{tabular}

${ }^{n s}$ Non-significant, ${ }^{* *}$ significant at $1 \%$ of probability and ${ }^{*}$ significant at $5 \%$ of probability by the $\mathrm{F}$ test.

There was influence $(p \leq 0.05)$ of storage time on strawberry fresh weight loss (Table 1), indicating that it was a result of the natural physiological process of the fruit. A weight loss of $0.3 \%$ occurred on the last day of conservation (12 days) in relation to the first day of fruit evaluation (day 0) (Figure 3).

Campos-Requena et al. (2017) mention that strawberry is highly susceptible to weight loss due to rapidly lose water, which causes skin damage due to tissue weakening and fruit shrinkage, having a negative effect on its appearance. The water loss causes the tissue to shrivel and wrinkle making them unacceptable for commercialization. For this reason, controlling fruit water loss becomes so important.

This behavior occurred in the present study, however, the fruit did not have a marked loss during the evaluation time and the epidermis remained intact reducing the water loss by perspiration and evaporation.

Garcia et al. (2008) report that the $\mathrm{pH}$ increases during the storage period due to the degradation of organic acids, such as malic acid and ascorbic acid, which occurs in the natural senescence process of the product; however, there was no change in the $\mathrm{pH}$ of strawberry fruit on active paper compared to those treated with paper without EO (Table 2).
In this study, the TSS and titratable acidity in strawberries had no active paper treatment effect $(p>0.05)$ when compared to the control (Table 2) during the storage period.

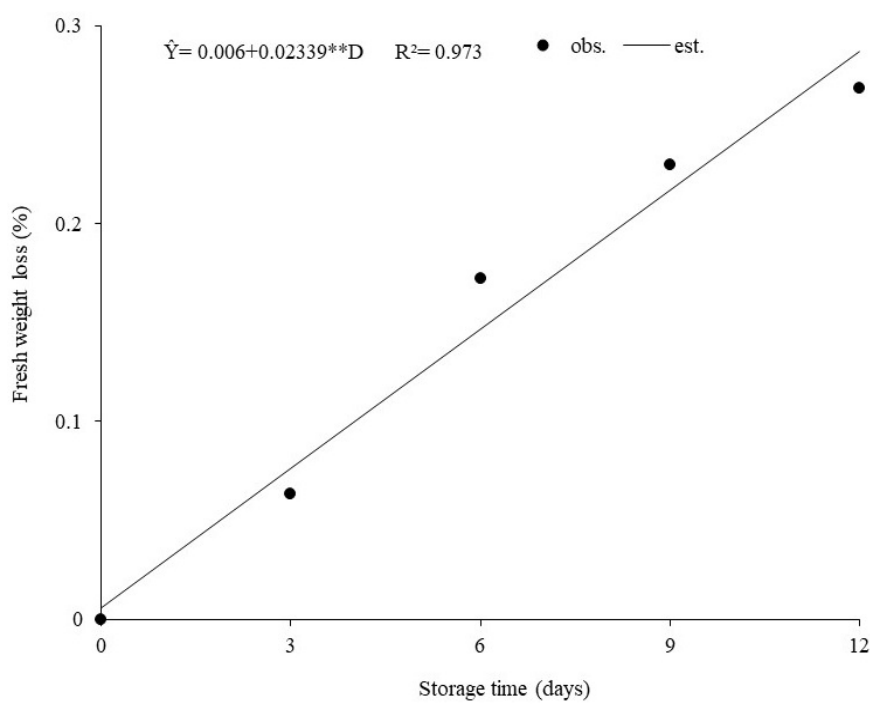

** Significant at $1 \%$ probability by $t$ test.

Figure 3. Fresh weight loss in strawberries wrapped in active paper under refrigeration $\left(8^{\circ} \mathrm{C}\right)$ as a function of storage time $(D)$.

Table 2. Mean values of the physicochemical analysis for the strawberry stored at $8{ }^{\circ} \mathrm{C}$.

\begin{tabular}{ccccccc}
\hline Treatment & Pulp color $\left(\mathrm{a}^{*}\right)$ & Epidermis color $\left(\mathrm{a}^{*}\right)$ & TSS ('Brix) & $\mathrm{pH}$ & Acidity (mL) & Firmness (N) \\
\hline 1 & $8.93 \mathrm{a}$ & $26.81 \mathrm{a}$ & $7.22 \mathrm{a}$ & $3.73 \mathrm{a}$ & $1.62 \mathrm{a}$ & $4.54 \mathrm{a}$ \\
2 & $7.39 \mathrm{~b}$ & $24.10 \mathrm{~b}$ & $6.98 \mathrm{a}$ & $3.66 \mathrm{a}$ & $1.64 \mathrm{a}$ & $3.71 \mathrm{~b}$ \\
\hline
\end{tabular}

\footnotetext{
* Means with different letters in the same column for each type of treatment show significant difference $(p<0.05)$ by the $F$ test.
} 
Similar result was presented by Campos-Requena et al. (2017) in strawberries inoculated with Botrytis cinérea for five days under conditions of indirect contact with nanocomposite films containing the EO association of carvacrol and thymol, without altering the fruit quality parameters or its organoleptic properties. Although titratable acidity did not change significantly, these values tended to slowly increase until the storage end.

There was difference $(p<0.05)$ in the pulp firmness of strawberries wrapped in $5 \%$ EO active paper $(3.71 \mathrm{~N})$ in relation to the control treatment $(4.54 \mathrm{~N})$. Although a negative effect on the firmness of fruit packed in an active paper was observed, a lesser microorganisms development in them was also verified.

Control a* values of the strawberries for pulp and epidermis were, respectively, 8.93 and 26.81. Cinnamaldehyde-treated strawberries a* values for pulp and epidermis were 7.39 and 24.10, respectively (Table 2). During storage, fruit treated with active paper showed opaque red color in the pulp and epidermis of strawberries, which may be due to the greater diffusion of volatile cinnamaldehyde EO compounds incorporated in the package. According to Peretto et al. (2014), a* values in strawberries (measure of redness) usually decrease over time, with the fruit losing its saturated red color.

The results of this study are in agreement with those from previous studies (Espitia et al., 2012), which also found no effect of active sachet-shaped packaging incorporated with EO on papaya quality parameters such as $\mathrm{pH}$, loss of weight, acidity and total soluble solids.

\section{Conclusions}

Active papers inhibited the development of Botrytis cinerea and Rhizophus stolonifer in vitro, reduced microbial growth in the strawberry and showed no adverse effects on the chemical quality of the treated strawberry fruit.

Fruits treated with active paper showed lower firmness and color of the pulp and of epidermis.

\section{Acknowlodgements}

To the National Council for Scientific and Technological Development - CNPq and the Coordination for the Improvement of Higher Education Personnel-CAPES, for the financial support and the scholarship concession.

\section{Literature Cited}

Aguilar-González, A. E.; Palou, E.; López-Malo, A. Antifungal activity of essential oils of clove (Syzygium aromaticum) and/or mustard (Brassica nigra) in vapor phase against gray mold (Botrytis cinerea) in strawberries. Innovative Food Science and Emerging Technologies, v.32, p.181-185, 2015. https://doi.org/10.1016/j. ifset.2015.09.003.

Association of Official Analytical Chemists - AOAC. Official methods of analyses of the Association of Official Analytical Chemists. 12 ed. Washington: AOAC, 1995.
Benato, E.A.; Belletti, T.C.; Terao, D.; Franco, D.A.S. Óleos essenciais e tratamento térmico no controle pós-colheita de bolor verde em laranja. Summa Phytopathologica, v.44, n.1, p.65-71, 2018. https://doi.org/10.1590/0100-5405/175659.

Boubaker, H.; Karim, H.; Hamdaoui, El; Msanda, A.; Leach, F.; Bombarda, D.; Vanloot, I.; Abbad, P.; Boudyach, A.; Ait Ben, E.H.; Aoumar, A. Chemical characterization and antifungal activities of four Thymus species essential oils against postharvest fungal pathogens of citrus. Industrial Crops and Products, v.86, p.95101, 2016. https://doi.org/10.1016/j.indcrop.2016.03.036.

Campos-Requena, V. H.; Rivasa, B. L.; Péreza, M. A.; Figueroa, C. R.; Figueroa, N. E.; Sanfuentes, E. A. Thermoplastic starch/ clay nanocomposites loaded with essential oil constituents as packaging for strawberries - In vivo antimicrobial synergy over Botrytis cinerea. Postharvest Biology and Technology, v.129, p.2936, 2017. https://doi.org/10.1016/j.postharvbio.2017.03.005.

Costa, H.; Ventura, J. A. Doenças do morangueiro: diagnóstico e manejo. In: Balbino, J. M. S. (Ed.). Tecnologias para produção, colheita e póscolheita de morangueiro. Vitória: Incaper, p. 41-57, 2006.

Cozmuta, A.M.; Turila, A.; Apjok, R.; Ciocian, A.; Cozmuta, L.M.; Peter, A.; Nicula, C.; Galic, N.; Benkovic, T. Preparation and characterization of improved gelatin films incorporating hemp and sage oils. Food Hydrocolloids, v.49, p.144-155, 2015. https:// doi.org/10.1016/j.foodhyd.2015.03.022.

Derbalah, A. S.; Dewir, Y. H.; El-Sayed. A. E.N. B. Antifungal activity of some plant extracts against sugar beet damping-off caused by Sclerotium rolfsii. Annals of Microbiology. v.62, n.3, p.1021-1029, 2012. https://doi.org/10.1007/s13213-011-0342-2.

Espitia, P.J.P.; Soares, N. de F.F.; Botti, L.C.M.; Melo, N.R. de; Pereira, O. L; Silva, W.A. da. Assessment of the efficiency packaging oils in the preservation of postharvest papaya in an antimicrobial packaging system. Brazilian Journal of Food Technology, v.15, n. 4, p.333-342, 2012. https://doi.org/10.1590/S198167232012005000027.

Ferreira, D. F. Sisvar: a computer statistical analysis system. Ciência e Agrotecnologia, v. 35, n.6, p. 1039-1042, 2011. https://doi. org/10.1590/S1413-70542011000600001.

Food and Drug Administration - FDA. Code of federal regulation (CFR), Title 21: Food and drugs. Chapter I - food and drug administration, department of (continued), Part 182 - substances generally recognized as safe (GRAS), subpart A - general provisions, subpart 182.21- essential oils, oleoresins, and natural extractives. Office of the Federal Register, Washington. https:// www.accessdata.fda.gov/scripts/cdrh/cfdocs/cfcfr/CFRSearch. cfm?fr=182.20. 30 Ago. 2018.

Garcia, C.; Horst, M. V.; Maia, A. J.; Leite, C. D.; Faria, C. M. D. R.; Schwan-Estrada, K. R. F. Óleo essencial de alecrim no controle de doenças da videira cultivar Cabernet Sauvignon. Revista Brasileira de Ciências Agrárias, v.12, n.4, p.452-457, 2017. https://doi. org/10.5039/agraria.v12i4a5477.

Garcia, R.; Alves, E. S. S.; Santos, M. P.; Aquije, G. M. F. V.; Fernandes, A. A. R.; Santos, R. B. D.; Ventura, J. A.; Fernandes, P. M. B. Antimicrobial activity and potential use of monoterpenes as tropical fruits preservatives. Brazilian Journal of Microbiology, v. 39, n.1, p. $163-168,2008$. https://doi.org/10.1590/S151783822008000100032 . 
Gorrasi, G.; Bugatti, V.; Tammaro, L.; Vertuccio, L.; Vigliotta, G.; Vittoria, V. Active coating for storage of Mozzarella cheese packaged under thermal abuse. Food Control, v. 64, p. 10-16, 2016. https://doi.org/10.1016/j.foodcont.2015.12.002.

Kerry, J. P. New packaging technologies, materials and formats for fastmoving consumer products. In: Han, J. H. (Ed.), Innovations in food packaging. 2.ed. San Diego: Academic Press, 2014. p. 549-584. https://doi.org/10.1016/B978-0-12-394601-0.00023-0.

Lorenzetti, E.R.; Monteiro, F.P.; Souza, R.J.; Scalice, H.K.; Diogo Jr, R.; Pires, M.S.O. Bioatividade de óleos essenciais no controle de Botrytis cinerea isolado de morangueiro. Revista Brasileira de Plantas Medicinais, v.13, n. especial, p.619-627, 2011. https:// doi.org/10.1590/S1516-05722011000500019.

Moura, G. S.; Jaski, J. M.; Franzener, G. Potencial de extratos etanólicos de propólis e extratos aquosos de plantas espontâneas no controle de doenças pós-colheita do morango. Revista Verde, v. 11, n.5, p.57-63, 2016. https://doi.org/10.18378/rvads.v11i5.4175.

Peretto, G.; Du, W.X.; Avena-Bustillos, R.J.; Sarrael, S.B.L.; Hua, S.S.T.; Sambo, P.; McHugh, T.H. Increasing strawberry shelf-life with carvacrol and methyl cinnamate antimicrobial vapors released from edible films. Postharvest Biology and Technology, v.89, p.1118, 2014. https://doi.org/10.1016/j.postharvbio.2013.11.003.

Quattara, B.; Simard, R.; Piette, G.; Begin, A.; Holley, R. A. Inhibition of surface spoilage bacteria in processed meats by application of 45 antimicrobial films prepared with chitosan. International Journal of Food Microbiology, v. 62, n.1-2, p. 139-148, 2000. https://doi. org/10.1016/S0168-1605(00)00407-4.
Soares, N.F.F. Bitterness reduction in citrus juice through naringinase immobilized into polymer film. New York: Cornell University, 1998. 130 p. Ph.D. Dissertation.

Stavropoulou, A.; Loulakakis, K.; Magan, N.; Tzortzakis, N. Origanum dictamnus oil vapour suppresses the development of grey mould in eggplant fruit in vitro. BioMed Research Corporation, v,2014, article 562679, 2014. https://doi.org/10.1155/2014/562679.

Vanderzant, C., Splittstoesser, D.F (Eds.). Compendium of methods for the microbiological examination of foods. 3.ed. Washington: APHA, 2001. 1219p.

Ventura-Aguilar, R. I.; Bautista-Baños, S.; Flores-Garcıa, G.; Zavaleta-Avejar, L. Impact of chitosan based edible coatings functionalized with natural compounds on Colletotrichum fragariae development and the quality of strawberries. Food Chemistry, v. 262, p. 142-149, 2018. https://doi.org/10.1016/j. foodchem.2018.04.063.

Vilaplana, R., Pazmiño, L.; Valencia-Chamorro, S. Control of anthracnose, caused by Colletotrichum musae, on postharvest organic banana by thyme oil. Postharvest Biology and Technology, v. 138, p.56-63, 2018. https://doi.org/10.1016/j. postharvbio.2017.12.008.

Wei, Y.; Shao, X.; Wei, Y.; Feng Xu, F.; Wang, H. Effect of preharvest application of tea tree oil on strawberry fruit quality parameters and possible disease resistance mechanisms. Scientia Horticulturae, v. 241, p.18-28, 2018. https://doi.org/10.1016/j. scienta.2018.06.077. 